of reliable professional skills in modern aircraft operation when conducting radio communication exclusively in English.

\title{
References:
}

1. Sue E., Terence G. English for Aviation (for Pilots and Air Traffic Controllers) / E. Sue, G. Terence, Oxford. 2001.95 p.

2. Harwood N. English Language Teaching. Materials, Theory and Practice/N. Harwood, Cambridge University Press. 2010. 488 p.

3. Hedge T. Teaching and Learning in the Language Classroom: A Guide to Current Ideas about the Theory and Practice of English Language Teaching/T. Hedge, Oxford. 2000. 464 p.

4. Cook, G. Discourse, Oxford University Press. 1989. 385p.

5. Мартынова Р. Ю. Педагогические основы интегрированного обучения образовательной и иноязычной речевой деятельности студентов неязыковых специальностей : монография. Одесса: «Освіта України». 2017. 208 с.

DOI https://doi.org/10.30525/978-9934-26-173-2-46

\section{ФОРМУВАННЯ ПСИХОФІЗІОЛОГІЧНОЇ НАДІЙНОСТІ МАЙБУТНІХ АВІАЦІЙНИХ ФАХІВЦІВ В КОНТЕКСТІ КОМПЕТЕНТНІСНОГО ПІДХОДУ}

\author{
Півень М. I. \\ кандидат педагогічних наук, дочент, \\ завідувач кафедри фізичної та психофізіологічної підготовки \\ Льотна академія Національного авіачійного університету \\ м. Кропивницький, Украӥна
}

Інтерес до феномену «психофізіологічна надійність» як до дидактичного конструкту якісної професійної освіти пояснюється розробкою проблем психологічної готовності курсантів-пілотів до льотної діяльності [1]. Широке коло наукових досліджень і багатолітня практика системної організації фізичної підготовки свідчить, що одним 3 можливих вирішень надзвичайно актуальної для льотної практики проблеми формування психофізіологічної надійності курсантів льотного ЗВО $є$ компетентнісно зорієнтована фізична i психофізіологічна підготовка (Ф і ПФП). Вона $€$ однією із форм творчого способу формування фізкультурно-оздоровчих компетентностей, то іiі 170 
правомірно вважати технологією переводу навчальної діяльності в режим особистісного розвитку, в режим, коли курсант стає суб'єктом навчальної діяльності, суб'єктом інтеграції психолого-педагогічних знань для рішення окреслених завдань. Беручи за основу підхід, відповідно до якого вміння - це засвоєний суб'єктом спосіб виконання дій, що забезпечується сукупністю педагогічних умов, визначаємо загальні чинники впливу на ефективність компетентнісно орієнтованої Ф і ПФП у формуванні психофізіологічної надійності курсантів-пілотів:

- конструювання змісту занять 3 фізичної підготовки необхідно здійснювати таким чином, щоб він був достатнім для формування окремих фізкультурно-оздоровчих компететностей та їх елементів з одного боку, з іншого - оптимізованим з точки зору часу для організації активної навчальної діяльності курсантів на заняттях і поза ними 3 опанування тих чи інших елементів окреслених компетентностей та психофізіологічної надійності;

- організація Ф і ПФП курсантів-пілотів здійснюється 3 дотриманням технології поетапного формування фізкультурно-оздоровчих компетентностей та технології саморегуляції фізкультурною самодіяльністю курсанта, яка містить обов'язкові складові як для викладача, так і для курсанта (суб'єкти навчальної діяльності);

- запровадження інтерактивного навчання, зокрема, прийомів, методів і форм організації активної теоретико-методичної і практичної підготовки, що можуть оптимально забезпечити компетентнісний результат у формуванні психофізіологічної надійності курсантівпілотів;

- приділення спеціальної уваги формуванню мотиваційного-ціннісного ставлення курсантів до планових занять Ф і ПФП та створенню умов для конструктивної самостійної фізкультурної діяльності коли курсант бере на себе відповідальність за досягнуті результати;

- обов'язкове врахування у процесі занять фізичною підготовкою комплексного оцінювання рівня розвитку загальних і спеціальних компонентів фізкультурно-оздоровчих компентностей, самостійності й вмотивованості курсантів, їх стану здоров'я, психофізіологічної надійності та психологічної готовності до майбутньої професії;

- створення сприятливого навчального середовища, позитивної психологічної атмосфери на заняттях.

Зауважимо на кількох важливих моментах. Компетентнісно орієнтована Ф і ПФП спрямована на оволодіння усім спектром фізкультурнооздоровчих компетентностей, однак досягнення цієї мети є можливим за умов наявності в особи потреби у постійному самовдосконаленні, сенсу самотворення й конструктивно-перетворювальної сили, яка здатна 
трансформувати фізкультурно-оздоровчі впливи для якнайповнішої актуалізації й реалізації індивідуальних потенційних можливостей курсанта в навчальній діяльності, і на цій основі визначити свій алгоритм розвитку психофізіологічної надійності, зреалізувати найважливіші особистісні смисли, цінності й мотиви в регулярних занять фізичними вправами. Очевидно, що для рішення цих важливих завдань на заняттях Ф і ПФП курсанту необхідні:

- знання 3 основ здорового способу життя, основ фізичної i психофізіологічної підготовки. Зрозуміло, що окреслені знання навряд чи можливо засвоїти, звертаючись до теорії системної організації $\Phi$ і ПФП побіжно, чи принагідно. Не досягнемо бажаного результату й за умови надмірного використання наукової інформації. Лише послідовно-акцентований спосіб подачі необхідної конкретної інформації служить перспективним підгрунтям для свідомого й надійного засвоєння окреслених знань. Йдеться не лише про передачу інформації від викладача до курсанта але й про забезпечення умов для розвитку $\mathrm{i}$ формування здібності курсанта до самостійного пошуку відповідних знань, уміння відсіяти від непотрібних та перевести їх у досвід власної фізкультурної діяльності;

- уміння бути суб'єктом навчальної діяльності та суб'єктом самотворення на заняттях з Ф і ПФП. Це уміння на перетворюючому рівні навчальної діяльності дозволяє виділити курсанта як системоутворюючого ядра, який постійно об'єднує і розділяє, інтегрує й диференціює в своєму віртуальному освітньому просторі навчальний матеріал компетентнісно орієнтованої Ф і ПФП в ії системності й цілісності, відкритості процесам професійного й особистісного саморозвитку;

- ціннісні орієнтації в теорії і практиці компетентнісно орієнтованої $\Phi$ і ПФП, які є основою суб'єктної позиції курсанта в навчальній діяльності та визначають, чи буде він діяти у тій чи іншій ситуації, наскільки рішуче, послідовно, відповідально. Власне, цінності, виконуючи функцію стимулів, створюють умови для реалізації активності курсанта на планових заняттях, самотворенні власного здоров'я i суб'єктності. Джерелом окресленого самотворення $є$ специфічні для фізкультурної діяльності потреби, насамперед - постійне фізичне та особистісне самовдосконалення. Саме Ф і ПФП як навчальна дисципліна створює основне підгрунтя для формування фізкультурно-оздоровчих компетпентностей курсанта-пілота загального і спеціального напрямку. Окрім цього, під іiі впливом та під впливом власних потреб формуються мотиви, стимули, які курсант усвідомлює у вигляді різноманітних інтересів до формувальних можливостей засобів фізичної підготовки. 
Стійкий розвинений інтерес сприяє розвитку певної спрямованості особистості, яку часто пов'язують з психологічною установкою на фізкультурну діяльність, способом реагування, готовністю тощо. Наявність установки особистості сприяе виникненню у неї емоційноціннісного ставлення до регулярних занять фізичними вправами. Таким чином, заняття набувають у свідомості курсанта статусу цінності, переконань i завершуются утворенням відносно стійких моделей фізкультурної самодіяльності, зокрема з розвитку психофізіологічної надійності й психологічної готовності до майбутньої професії;

- відбір та відповідне структурування програмного змісту фізичної підготовки з урахуванням психологічного механізму формування позитивного ставлення курсанта до планових занять. Тобто, треба включати до змісту занять факти про те, якими були потреби, мотиви, інтереси авіаційних фахівців, які створили такі цінності і прагнули втілити їх у льотну діяльність; як вони ставились до занять фізичними вправами і спортом; як діяли в штатній чи позаштатній ситуаціях льотної діяльності, спираючись на власний фізичний розвиток і здоров'я;

- рефлексивність змісту занять 3 фізичної підготовки має створювати умови для усвідомлення курсантами способів та результатів власної навчальної діяльності у процесі розвитку фізкультурно-оздоровчих компетентностей. Вся система оцінювання має бути орієнтована, 3 одного боку, на усвідомлення курсантом змісту заняття, а з іншого - на послідовну рефлексію власних здобутків, адекватного оцінювання особистісних перевершувань в розвитку фізкультурно-оздоровчих компетентностей загального і спеціального напряму, збагачення досвіду застосування методичного арсеналу, оцінки внутрішніх станів (симпатія, натхнення, схвалення, зацікавленість, відданість тощо). Але насправді, якщо ми говоримо про розвиток особистості курсанта й компетентнісний підхід до організації Ф і ПФП, то маємо думати про моніторинг якості оцінки отриманих результатів. Крім того, мусимо чітко уявляти, якою є мета нашого оцінювання. У разі, якщо нашою метою є стимулювання курсанта до саморозвитку, тоді ми навіть не будемо оцінювати його самі - потрібно підібрати такі контрольні вправи, тести, опитувальники, що дозволять, залучити його до самооцінювання. Що для нас $є$ показником досягнення бажаного результату на заняття з Ф і ПФП? Якщо дійсно ми дбаємо про розвиток у курсанта фізкультурно-оздоровчих компетентностей загального і спеціального напряму, про розвиток психофізіологічної надійності, його особистості й конструктивної самодіяльності ми повинні чітко знати що буде оцінюватись на заняттях та яким чином. Загальновідомо, що оцінювання має бути відкритим, абсолютно ясним і прозорим, тоді воно стимулює 
до саморозвитку. Тобто, курсант разом 3 викладачем оцінюють не відповідність отриманого показника до контрольного нормативу, a рівень зростання (покращення) конкретного показника, шляхом порівняння показників - фонового 3 поточним. Відсоток зростання показника буде свідчити про певний рівень розвитку в курсанта окресленої компетентності: початковий, достатній, зразковий.

Отже, компетентнісно орієнтована Ф і ПФП потребує зламу певних стереотипів як у плануванні занять, так і в оцінюванні індивідуальних досягнень курсантів-пілотів у розвитку їх психофізіологічної надійності. Все це потребує відповідної практики і конструктивних теоретичних напрацювань.

Література:

1. Макаров Р.Н. Фурдуй Я.О. Научные основы физической подготовки летного состава. М, 2007. 920 с.

2. Пивень М.И., Ищенко А.В. Специальная физическая и психофизиологическая подготовка курсантов-пилотов. Кировоград: КДПУ, 2016. 248 с.

DOI https://doi.org/10.30525/978-9934-26-173-2-47

\title{
THE USE OF GRAPHIC LITERACY IN THE CONSTRUCTION OF IMAGES IN THE STUDY OF PERSPECTIVE IN EDUCATIONAL INSTITUTIONS OF PROFESSIONAL, TECHNICAL, ART AND PEDAGOGICAL ORIENTATION
}

\author{
Poltorak A. V. \\ Senior lecturer of the department of technological \\ and professional education \\ State Institution "South Ukrainian National Pedagogical University \\ named after K. D. Ushinsky" \\ Odessa, Ukraine
}

In our time of rapid scientific and technological progress, graphic literacy is a necessary component of everyone's education. Drawings accompany us all our lives, helping us to understand the various issues of science, technology, art and education.

The scientist O. Zaika gives an interpretation of the concept of "Graphic Literacy" as the ability to read various graphic images (drawings, diagrams, 174 